2

I N S A N

\title{
INSAN
}

Jurnal Psikologi dan Kesehatan Mental

http://e-journal.unair.ac.id/index.php/JPKM

p-ISSN 2528-0104 | e-ISSN 2528-5181

ARTIKEL PENELITIAN

\section{Learned Helplessness pada Wanita Dewasa Awal Korban Kekerasan dalam Pacaran yang Masih Bertahan dengan Pasangannya}

NIKEN CITHA ANANDA \& HAMIDAH*

Departemen Psikologi Klinis dan Kesehatan Mental, Fakultas Psikologi Universitas Airlangga

\begin{abstract}
ABSTRAK
Tujuan penelitin ini untuk mengetahui learned helplessness pada wanita dewasa awal korban kekerasan dalam pacaran yang masih bertahan. Learned helplessness adalah kondisi yang muncul karena ketidakmampuan individu mengatasi atau menghentikan peristiwa negatif yang terjadi terus menerus sehingga menyebabkan penurunan respon. Learned helplessness dibagi menjadi tiga dimensi yaitu penurunan motivasi, penurunan kognitif dan penurunan emosi. Penelitian ini mneggunakan teori learned helplessness milik Seligman (1975). Penelitian ini menggunakan metode kualitatif dengan pendekatan studi kasus instrumental, menggunakan analisis tematik theory-driven. Partisipan berjumlah 3 wanita dewasa awal berusia 22-23 tahun yang mengalami kekerasan dalam pacaran dan masih bertahan dengan pasangannya. Hasil penelitian menunjukkan bahwa ketiga subjek mengalami kondisi learned helplessness. Faktor yang memengaruhi munculnya learned helplessness pada ketiga subjek adalah fase kekerasan, kekerasan psikologis dan faktor power dan kontrol yang dimiliki pelaku. Ketiga subjek mengalami penurunan motivasi, penurunan kognitif dan penurunan emosi.
\end{abstract}

Kata kunci: kekerasan dalam pacaran, learned helplessness, wanita dewasa awal

\begin{abstract}
This research aimed to explain learned helplessness in early adult women who were victims of dating violence, yet they still maintain the relationship. Learned helplessness is a condition where individuals are no longer able to cope or stop negative events that occurs continuously, promoting response deficit. There are three learned helplessness dimensions: motivational deficit, cognitive deficit, and emotional deficit. This study used Seligman's (1975) learned helplessness theory. This was qualitative study with instrumental case study approach. The framework used was thematic analysis using theory driven approach. This study involved 3 early adult women aged 22-23 years old who experienced dating violence yet still maintain the relationship. The results showed that all participants experienced learned helplessness. There were three factors that influenced the learned helplessness; there was cycle of violence, psychological violence, and power and control factor by the perpetrators. All participants demonstrated motivational deficit, cognitive deficit, and emotional deficit.
\end{abstract}

Key words: dating violence, early adult women, learned helplessness 
INSAN Jurnal Psikologi dan Kesehatan Mental, 2019, Vol. 4(1), 36-42, doi: 10.20473/jpkm.v5i22018.36-42 Dikirimkan: 16 Oktober 2019 Diterima: 10 Desember 2019 Diterbitkan: 27 Februari 2020

Editor: Rizqy Amelia Zein

*Alamat korespondensi: Fakultas Psikologi Universitas Airlangga, Jalan Airlangga 4-6 Surabaya 60286. Pos-el: hamidah@psikologi.unair.ac.id

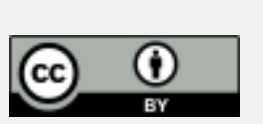

Naskah ini merupakan naskah dengan akses terbuka dibawah ketentuan the Creative Common Attribution License (http://creativecommons.org/licenses/by/4.0), sehingga penggunaan, distribusi, reproduksi dalam media apapun atas artikel ini tidak dibatasi, selama sumber aslinya disitir dengan baik.

\section{PEN D A H U L U A N}

Manusia memiliki tugas perkembangan saat memasuki fase dewasa awal, salah satunya adalah membangun hubungan romantis dengan pasangan atau lawan jenis (Santrock, 2011). Hubungan romantis yang disebut juga dengan pacaran merupakan hubungan dua arah interaksi sosial dan melakukan kegiatan bersama-sama untuk melanjutkan hubungan yang memiliki komitmen. Hubungan pacaran akan ada permasalahan yang memunculkan konflik, dan jika konflik tidak dapat diselesaikan, maka penggunaan kekerasan akan muncul sebagai salah satu penyelesaian masalah (Straus et al., 2004).Kekerasan dalam pacaran merupakan suatu penggunaan taktik dan pemaksaan fisik yang dilakukan secara sengaja dengan tujuan mempertahankan dan mengontrol pasangan secara penuh. Kekerasan pacaran dibagi menjadi tiga, yaitu kekerasan verbal/emosional, kekerasan seksual, dan kekerasan fisik yang muncul terakhir kali. Kekerasan pacaran rentan terjadi pada usia remaja karena pada fase remaja kekerasan tidak dianggap suatu permasalahan yang serius (Murray, 2007). Kekerasan pacaran yang berlanjut hingga masa dewasa akan menjadi lebih parah karena berpotensi terjadinya KDRT (Loka, 2017).

Kekerasan pacaran dapat terjadi pada perempuan dan laki-laki, namun dalam kenyataannya lebih banyak perempuan yang menjadi korban (Kaura \& Lohman, 2007). Adanya budaya patriarki dimana perempuan ditempatkan dibawah laki-laki, perempuan harus patuh, tunduk, pasrah, berbakti, dan setia dengan pasangannya (Hehanusa, 2014). Hal ini sesuai dengan Catahu Komnas Perempuan, dimana KDP merupakan kasus kekerasan yang mengalami kenaikan secara signifikan. Pada tahun 2018 kasus KDP mengalami kenaikan sebesar 2\% dengan jumlah 2.073 kasus (Komnas Perempuan, 2019).

Bentuk KDP yang dilakukan pada perempuan akan mengakibatkan dampak secara fisik, psikologis dan sosial. Dampak yang dirasakan korban akan menyebabkan korban memilih pergi dari pasangannya, namun dalam kenyataan dan berdasarkan penelitian sebelumnya masih ada korban yang bertahan dengan pelaku. Penelitian menyebutkna beberapa alasan korban bertahan dengan pelaku KDP antara lain karena adanya komitmen dari pasangan, faktor pendidikan, dan ekonomi (Bell \& Naugle, 2005), ancaman bunuh diri dari pelaku apabila korban meninggalkannya (Barnett, 2000), tidak adanya dukungan sosial (Estrellado \& Loh, 2014), self-blame, takut pelaku akan balas dendam, percaya pasangan akan berubah, dan learned helplessness (Eckstein, 2010).

Learned helplessness merupakan suatu kondisi yang muncul karena ketidakmampuan individu dalam mengatasi peristiwa negatif yang terjadi terus menerus. Munculnya persepsi bahwa respon yang diberikan akan menghasilkan hasil akhir yang sama, namun dalam kenyataannya hasil akhir yang didapatkan tidak sesuai dengan respon yang diberikan sehingga memunculkan penurunan keinginan untuk merespon (Seligman, 1975). Individu yang mengalami learned helplessness cenderung 
mengatribusikan suatu peristiwa negatif sebagai personalisasi internal, generalisasi kegagalan, dan permanen (Miller, 2006).

Konsep learned helplessness pada wanita korban kekerasan dikemukakan pertama kali oleh Walker dalam battered women syndrome (Palker-corell \& Marcus, 2004; Walker, 2009). Wanita belajar menjadi tidak berdaya karena menerima kekerasan berulang kali, tidak dapat diprediksi, tidak mampu, dan memunculkan belief bahwa mereka tidak memiliki kontrol atas situasi tersebut (Palker-corell \& Marcus, 2004), sehinggahal tersebut menyebabkan penurunan dalam usaha meninggalkan pasangan atau menghentikan kekerasan yang terjadi (Bell \& Naugle, 2005; Walker, 2009). Beberapa faktor pendukung yang memengaruhi munculnya learned helplessness pada korban kekerasan adalah fase penganiayaan, kekerasan seksual, faktor power, dan kontrol pelaku, ancaman pembunuhan dari pelaku, kekerasan psikologis, pengalaman kekerasan korban dan pengaruh alkohol dan obat-obatan (Walker, 2009).

Penelitian learned helplessness di Indonesia dilakukan oleh Syafitri (2011) mengenai proses munculnya learned helplessness. Learned helplessness muncul karena sikap dan perilaku yang tidak dapat diprediksi, tidak mampu menemukan strategi koping yang sesuai, adanya ekspektasi hasil dari respon yang diberikan korban kepada pelaku sehingga memunculkan sikap pasif. Seligman (1975) menyatakan learned helplessness akan menghasilkan belief bahwa individu tidak akan bisa mengatasi peristiwa negatif yang sama yang menghasilkan penurunan pada tiga hal yaitu motivasi, kognitif dan emosi.

Penelitian ini berfokus pada wanita dewasa awal korban kekerasan dalam pacaran yang masih bertahan dengan pasangannya. Penelitian ini bertujuan untuk bagaimana learned helplessness pada wanita korban kekerasan dalam pacaran yang bertahan dengan pasangannya.

\section{ME T O D E}

Metode kualitatif digunakan dalam penelitian ini dengan pendekatan studi kasus instrumental. Partisipan penelitian ditentukan menggunakan purposive participant dengan kriteria subjek antara lain:

1) Wanita dewasa awal yang berusia 18-25 tahun

2) Sedang menjalin hubungan pacaran

3) Mengalami kekerasan pacaran dan masih bertahan dengan pasangannya saat ini

4) Memenuhi atribusi terjadinya kejadian negative

Penggalian data dilakukan dengan teknik wawancara mendalam dengan catatan lapangan pada subjek. Wawancara dilakukan setelah peneliti menyusun pedoman umum wawancara yang didasarkan pada teori learned helplessness milik Seligman (1975). Analisis tematik theory-driven digunakan untuk teknik analisis data. Member-checking dan peningkatan ketekunan sebagai teknik kredibilitas data.

HAS IL PE N EL I T IAN

Partisipan penelitian ini terdiri atas tiga partisipan, berikut adalah tabel gambaran partisipan penelitian:

Tabel 1. Gambaran Partisipan Penelitian

\begin{tabular}{llll}
\hline \multicolumn{1}{c}{ Keterangan } & \multicolumn{1}{c}{ Subjek 1 } & Subjek 2 & Subjek 3 \\
\hline Usia & 23 tahun & 22 tahun & 23 tahun \\
\hline Pendidikan & S1 & S1 & S1 \\
\hline Lama Pacaran & 3 tahun 4 bulan & 2 tahun 2 bulan & 4 tahun \\
\hline Mengalami KDP sejak & 1 tahun 6 bulan pacaran & 6 bulan pacaran & 1 tahun pacaran \\
\hline Bentuk KDP & Verbal, Emosional, Fisik & Verbal, Emosional, Fisik & Verbal, Emosional, Fisik \\
\hline $\begin{array}{l}\text { INSAN Jurnal Psikologi dan Kesehatan Mental } \\
\text { 2019, Vol. 4(1), 36-42 } \\
\text { doi: } 10.20473 / \text { jpkm.v5i22018.36-42 }\end{array}$ & &
\end{tabular}


Ketiga subjek penelitian memenuhi indikator atribusi learned helplessness:

Tabel 2. Atribusi Learned Helplessness

\begin{tabular}{lccc}
\hline \multicolumn{1}{c}{$\begin{array}{c}\text { Atribusi Learned } \\
\text { Helplessness }\end{array}$} & Subjek 1 & Subjek 2 & Subjek 3 \\
\hline Personalisasi Internal & $\sqrt{ }$ & $\sqrt{ }$ & $\sqrt{ }$ \\
\hline Generalisasi Kegagalan & $\sqrt{ }$ & $\sqrt{ }$ & $\sqrt{ }$ \\
\hline Permanen & $\sqrt{ }$ & $\sqrt{ }$ \\
\hline
\end{tabular}

Faktor pendukung munculnya learned helplessness pada ketiga subjek hanya memenuhi tiga faktor, berikut adalah tabel faktor pendukung munculnya learned helplessness:

Tabel 3. Faktor Munculnya Learned Helplessness

\begin{tabular}{lccc}
\hline \multicolumn{1}{c}{ Faktor LH } & Subjek 1 & Subjek 2 & Subjek 3 \\
\hline Pola kekerasan & $\sqrt{ }$ & $\sqrt{ }$ & $\sqrt{ }$ \\
\hline Kekerasan seksual & - & - & $\sqrt{ }$ \\
\hline $\begin{array}{l}\text { Faktor } \text { power dan } \\
\text { kontrol pelaku }\end{array}$ & $\sqrt{ }$ & $\sqrt{ }$ & - \\
\hline Ancaman pembunuhan & - & - & $\sqrt{ }$ \\
\hline Kekerasan psikologis & $\sqrt{ }$ & $\sqrt{ }$ & - \\
\hline $\begin{array}{l}\text { Pengalaman kekerasan } \\
\text { korban }\end{array}$ & - & - & - \\
\hline $\begin{array}{l}\text { Penggunaan alkohol dan } \\
\text { obat-obatan korban }\end{array}$ & - & - & \\
\hline
\end{tabular}

Ketiga subjek mengalami penurunan motivasi, kognitif, dan emosi. Penurunan motivasi korban untuk merespon kekerasan yang dialami terjadi ketika korban belajar bahwa respon yang diberikan terhadap perilaku kekerasan yang terjadi tidak menghasilkan hasil yang sesuai dengan ekspektasi mereka. Penurunan kognitif ditunjukkan dengan korban yang percaya bahwa pasangannya tidak akan berubah jika bukan dari keinginannya sendiri, berkurangnya persepsi kontrol individu untuk meninggalkan pasangannya, dan kesulitan dalam mempelajari respon sukses untuk meninggalkan pasangannya. Penurunan emosi ditunjukkan dengan korban merasa stres, tertekan, dan cemas dengan perilaku kasar pasangannya.

\section{I S K U S I}

Ketiga subjek mengalami ketiga penurunan yang memunculkan learned helplessness menurut Seligman (1975). Korban mengalami penurunan motivasi yang ditandai dengan berkurangnya usaha korban untuk keluar dari kekerasan yang dialami, penurunan dalam merespon kekerasan yang dilakukan pasangannya, korban menjadi pasif, dan korban menjadi menunda pekerjaan yang ada. Korban menyembunyikan perilaku abusif pasangannya dari keluarga dan orang terdekat karena adanya rasa malu yang dimiliki korban apabila keluarga atau orang terdekat mengetahui perilaku pasangannya yang akan menyebabkan dirinya diminta untuk meninggalkan pasangannya. Hal ini sesuai dengan penelitian milik Felson, Messner, Hoskin, \& Deane (2002) dimana korban menganggap kekerasan adalah hal privasi sehingga mereka tidak melaporkan ke orang terdekat atau ke polisi.

Penurunan kognitif ditunjukkan dengan menurunnya persepsi kontrol individu untuk meninggalkan atau mengubah pasangannya. Pola asuh, faktor kepribadian pelaku menjadi faktor penyebab korban

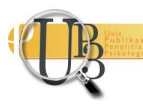


percaya tidak dapat mengubah pasangannya kecuali keinginan pasangannya sendiri. Hal ini sesuai dengan pernyataan Murray (2007) bahwa kekerasan dalam pasanganan dapat berhenti jika pelaku berinisiatif untuk menghentikannya. Korban mengalami kesulitan dalam mempelajari respon sukses untuk meninggalkan pasangannya, sehingga korban merasa dirinya akan berada dalam hubungan pacaran dalam jangka waktu yang lama. Kegagalan korban dalam mengontrol kekerasan yang terjadi dikarenakan usaha dan respon yang diberikan tidak menghasilkan hasil yang sesuai dengan ekspektasi.

Korban yang mengalami kekerasan pacaran dapat memunculkan trauma yang menyebabkan rasa takut. Rasa takut yang tidak dapat dialami akan memunculkan kondisi depresi. Korban mengalami stres dan sedih yang berkepanjangan karena memikirkan perilaku kasar pasangannya. Korban memiliki kecemasan dan merasa tertekan dengan perilaku pasangannya yang dapat melakukan kekerasan tanpa adanya penyebab yang jelas. Hal ini sesuai dengan dampak kekerasan yang dialami oleh korban seperti merasa cemas, merasa takut, dan tertekan dan munculnya rasa waspada yang berlebihan (Safitri \& Sama'i, 2013).

Fase kekerasan yang dilalui berulang kali oleh korban menyebabkan munculnya kondisi learned helplessness. Korban mengalami ketiga fase tersebut yaitu, tension building, acute battering incident, dan loving contrition. Learned helplessness akan muncul ketika fase pertama terjadi, karena korban akan berpikiran bahwa dirinya mampu mengontrol pasangannya sehingga memunculkan suatu belief (Walker, 2009). Selain fase kekerasan, faktor lain seperti kekerasan psikologis, adanya faktor kontrol dan power pelaku menjadi faktor pendukung munculnya learned helplessness.

Munculnya learned helplessness terjadi ketika korban memasuki bulan 18-28 dari total hubungan pacarannya. Korban mulai menunjukkan penurunan dalam merespon kekerasan yang dialaminya dan menjadi pasif untuk merespon. Penelitian sebelumnya tidak menyebutkan kapan learned helplessness muncul, dalam penelitian ini peneliti menemukan pada bulan ke 7-18 korban yang mengalami kekerasan pacaran mengalami penurunan respon pada bulan ke 18-28.

Alasan korban masih bertahan dengan pasangannya saat ini karena korban masih sayang dan cinta dengan pasangannya, adanya komitmen yang diberikan pasangannya, adanya ekspektasi dan harapan dari orang terdekat pasangannya dan takut tidak adanya alternatif hubungan lain jika memutuskan pasangannya.

\section{S I M P U L A N}

Kesimpulan dari penelitian ini adalah wanita dewasa awal yang menjadi korban kekerasan dalam pacaran mengalami kondisi learned helplessness yang mengakibatkan korban bertahan dengan pasangannya. Korban mengalami penurunan dalam merespon dan usaha untuk keluar dari peristiwa negatif karena munculnya hasil yang tidak sesuai dengan respon yang diberikannya. Penurunan motivasi, kognitif, dan emosi terjadi pada ketiga subjek.

Faktor yang memengaruhi munculnya learned helplessness adalah fase kekerasan yang terjadi berulang kali, kekerasan psikologis dan adanya faktor power dan kontrol pelaku terhadap korban.

Saran yang diberikan untuk korban kekerasan dalam pacaran adalah berlatih untuk mengambil keputusan yang tidak merugikan diri sendiri, mencari dukungan sosial untuk pengambilan keputusan, dan menghubungi tenaga professional untuk mendapatkan bantuan agar tidak mengalami kondisi patologis.

Saran untuk keluarga atau orang terdekat korban adalah memberikan dukungan dan pendampingan pada korban, memberikan masukan yang bijaksana pada korban dan menyarankan korban untuk menemui tenaga professional jika keadaan semakin parah.

INSAN Jurnal Psikologi dan Kesehatan Mental

2019, Vol. 4(1), 36-42

doi: 10.20473/jpkm.v5i22018.36-42 
Penelitian berikutnya diharapkan melibatkan lebih banyak partisipan dan menggali data yang lebih banyak. Kedua, peneliti berikutnya dapat membandingkan tingkat learned helplessness yang dialami korban kekerasan dalam pacaran atau perbandingan pada korban yang memiliki riwayat kekerasan dan tidak memiliki riwayat kekerasan. Pengembangan skala learned helplessness pada korban kekerasan juga diharapkan dapat dilakukan pada penelitian berikutnya.

\section{UCAPAN TERIMAKASIH}

Penulis mengucapkan terima kasih pada seluruh responden yang terlibat dalam penelitian ini sehingga penelitian ini dapat terselesaikan dengan baik.

\section{DEKLARASI POTENSI TERJADINYAKONFLIK KEPENTINGAN}

Niken Citha Ananda dan Hamidah tidak bekerja, menjadi konsultan, memiliki saham, atau menerima dana dari perusahaan atau organisasi mana pun yang akan mengambil untung dari naskah ini, dan telah mengungkapkan bahwa ia tidak memiliki afiliasi selain yang telah disebut di atas.

\section{PUSTAKA ACUAN}

Barnett, O. W. (2000). Why Battered Women Do Not Leave? Part 1: External Inhibiting Factors Within Society. Journal of Trauma, Violence and Abuse, 1(4), 343-373.

Bell, K. M., \& Naugle, A. E. (2005). UNDERSTANDING STAY/LEAVE DECISIONS IN VIOLENT RELATIONSHIPS : A BEHAVIOR ANALYTIC APPROACH. Journal of Behavioral and Social Issues, 14, 21-45.

Eckstein, J. J. (2010). Reasons for Staying in Intimately Violent Relationships : Comparisons of Men and Women and Messages Communicated to Self and Others. Journal Family Violence, 26(1), 21-30. https://doi.org/10.1007/s10896-010-9338-0

Estrellado, A. F., \& Loh, J. (2014). Factors Associated with Battered Filipino Women's Decision to Stay or Leave an Abusive Relationship. Journal of Interpersonal Violence, (November 2013). https://doi.org/10.1177/0886260513505709

Felson, R. B., Messner, S. F., Hoskin, A. W., \& Deane, G. (2002). Reasons for Reporting and Not Reporting Domestic Violence to the Police. Journal of Criminology, 40(3), 617-648. https://doi.org/10.1111/j.1745-9125.2002.tb00968.x

Hehanusa, M. (2014). KEKERASAN TERHADAP PEREMPUAN PERSPEKTIF HUKUM, BUDAYA DAN GENDER. Jurnal Fakultas Hukum, 9(1), 72-86.

Kaura, S. A., \& Lohman, B. J. (2007). Dating violence victimization, relationship satisfaction, mental health problems, and acceptability of Violence: A comparison of men and women. Journal of Family Violence, 22(6), 367-381. https://doi.org/10.1007/s10896-007-9092-0

Komnas Perempuan. (2019). Catatan Kekerasan Terhadap Perempuan Tahun 2019: Korban Bersuara, Data Bicara Sahkan RUU Penghapusan Kekerasan Seksual Sebagai Wujud Komitmen Negara. Jakarta.

Loka, W. A. V. (2017). Mindful Self-Compassion Therapy untuk Menurunkan Tingkat Self-Blame pada Perempuan Korban Kekerasan dalam Pacaran. Universitas Surabaya.

Miller, D. K. (2006). The effects of childhood physical abuse or childhood sexual abuse in battered

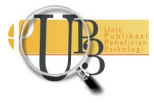


women's coping mechanisms: Obsessive-compulsive tendencies and severe depression. Journal of Family Violence, 21(3), 185-195. https://doi.org/10.1007/s10896-006-9019-1

Murray, J. (2007). But I Love Him: Protecting Your Teen Daughter from Controlling, Abusive Dating Relationships. New York: Harper Collins Publisher.

Palker-corell, A. N. N., \& Marcus, D. K. (2004). LEARNED HELPLESSNESS PARTNER ABUSE , LEARNED HELPLESSNESS , AND TRAUMA SYMPTOMS. Journal of Social and Clinical Psychology, 23(4), 445462.

Safitri, W. A., \& Sama'i. (2013). Dampak Kekerasan dalam Pacaran. Artikel Ilmiah Hasil Penelitian Mahasiswa UNEJ, 1(1), 1-6.

Santrock, J. W. (2011). Life-Span Development: Thirteenth Edition (Thirteenth). New York: McGraw-Hill.

Seligman, M. E. P. (1975). Helplessness on Depression, Development and Death. San Fransisco: W.H Freeman and Company.

Straus, M. A., Aldrighi, T., Alvarez, S., Atan, A., Boeckmann, I., Sieber, C., ... Savage, S. A. (2004). Prevalence of violence against dating partners by male and female university students worldwide. Violence Against Women, 10(7), 790-811. https://doi.org/10.1177/1077801204265552

Syafitri, N. (2011). Dinamika Proses Terjadinya Learned Helplessness pada Perempuan yang Mengalami Kekerasan Dalam Rumah Tangga. Skripsi2. Universitas Sumatera Utara.

Walker, L. E. A. (2009). The Battered Woman Syndrome: The 3rd Edition (Third). New York: Springer Publishing Company 